\title{
Punk, klass och karriär
}

\section{Per Dannefjord \& Magnus Eriksson}

SAmmandraG: Punken, musikstilen och ungdomsrörelsen som bröt fram under andra halvan av 1970-talet, är samtidigt både omskriven och svår att ringa in. Med sin undersökning av vad punken betytt som socialt sammanhang för dem som var med, lägger Per Dannefjord och Magnus Eriksson en pusselbit till vår förståelse av denna ökända ungdomskultur. I artikeln jämför de den sociala bakgrunden och den nuvarande klasspositionen för den första generationens punkare i Sverige, aktiva mellan 1978 och 1982. Tvärtemot vad olyckskorpar under "punkeran" trodde, visar det sig att punkarna lyckats bättre vad gäller både utbildningsnivå och social position jämfört med sin generation som helhet. Dannefjord och Eriksson ger två förklaringar till framgången: dels att punkens socialt brokiga sammansättning skapade en miljö där nya möjligheter blev synliga för framför allt ungdomar med arbetarbakgrund; dels att punken erbjöd läroprocesser som gav resurser som kunde utnyttjas i yrkes- och utbildningskarriärer inom framför allt kultursektorn.

NYCKELORD: punkrörelsen; ungdomskultur; motkultur; subkultur; klassresor; social mobilitet; utbildningskarriär; yrkeskarriär; kulturarbetare.

PUbLICERINGSHISTORIK: Originalpublicering. En till engelska översatt version av den här artikeln har tidigare publicerats som "Punk, class and career", i Sven Hort (red.), From Linnaeus to the future(s) - letters from afar, Linnaeus University Press 2010.

PER DANNEFJORD är lektor i sociologi vid Linnéuniversitetet.

E-POSTADRESS: per.dannefjord@lnu.se

MAGNUS ERIKSSON är utredare vid Linnéuniversitetet.

E-POSTADRESS: magnus.eriksson@lnu.se

FÖRSLAG PÅ KÄLLANGIVELSE:

Dannefjord, Per \& Magnus Eriksson (2013) "Punk, klass och karriär", i Arkiv. Tidskrift för sambällsanalys, $\mathrm{nr} \mathrm{I}, \mathrm{s}$. 97-II3. DoI: http://dx.doi.org/I0.I3068/2000-6217.I.5

(C) Författarna/Arkiv förlag \& tidskrift 20I3 (publicerad I3 december 20I3)

Artikeln distribueras enligt en upphovsrättslicens från Creative Commons:

Erkännande-Ickekommersiell-IngaBearbetningar 3.o Unported, som medger fri ickekommersiell användning och spridning i oförändrat skick så länge källan anges. 
Arkiv. Tidskrift för samhällsanalys är en sakkunniggranskad vetenskaplig tidskrift för samhällsvetenskap och historia. Samtliga artiklar publiceras fritt tillgängliga på:

www.tidskriftenarkiv.se

(beständig länk, DoI: http://dx.doi.org/IO.I3068/2000-62I7)

Den här artikeln finns tillgänglig i följande format:

PDF \& HTML: via beständig länk, DOI: http://dx.doi.org/IO.I3068/2000-62I7.I.5

EPUB: ingår i e-boksutgåva av numret, ISBN: 978 9I 79242503

TRYCK: ingår i bokutgåva av numret, ISBN: 978 9I 7924 25I O

Grafisk utformning och sidnumrering är identisk i pdf och tryck.

Samtliga artiklar i nr I (2013) nås via beständig länk, DOI: http://dx.doi.org/I0.13068/2000-6217.I

Arkiv. Tidskrift för sambällsanalys ISSN: 2000-62I7 (för elektronisk resurs)

ISSN: 2000-6225 (för tryckta nummer)

ges ut av

Stiftelsen Arkiv för främjande och spridning av samhällsvetenskaplig och historisk forskning

genom

Arkiv förlag \& tidskrift

Box 1559

SE-22I OI Lund

BESÖK: L Gråbrödersg 3 c, ipg

TEL: O46-I3 3920

ARKIV FÖRLAG: arkiv@arkiv.nu·www.arkiv.nu

TIDSKRIFTEN ARKIV: red@tidskriftenarkiv.se · www.tidskriftenarkiv.se

ANSVARIg UTGIVARE \& CHEFREDAKTÖR: Sven Hort

ADMINistrativ RedAKTÖr: David Lindberg

RedAKtörer: Paavo Bergman, Lisa Kings, Zhanna Kravchenko 


\section{Punk, klass och karriär}

\section{PER DANNEFJORD \& MAGNUS ERIKSSON}

I slutet av 1970-talet blev punken synlig i Sverige som musikstil, klädstil och uttryck i största allmänhet. Punken var inte ny utan hämtades, som så mycket annan ungdomskultur, från England och USA, men runt 1978 hände något nytt för svenska förhållanden. Till skillnad från tidigare ungdomskulturer var punken politisk, men utan politiska mål, och stilmedveten, men på ett öppet provokativt sätt.

I977 handlade det inte om antirasism eller antikommersialism utan om en ren anti-kultur. Anti allt som varit. Anti allt som var gammalt. "Summer of hate" var ett svar på peacemärken, blommor och "Summer of love". ("Marita" i Carlsson, Johansson \& Wickholm 2004: 13)

För vuxengenerationen och för andra ungdomsgrupper var punken inte bara svår att kategorisera utan också högljudd, skränig och saknade till synes mål och mening. Vi vågar påstå att det är sällsynt med ungdomsrörelser som är så sammanhållna som punken samtidigt som de är svåra att få grepp om. Den vänsterrörelse som utvecklades till politiska partier och en utbredd musikrörelse var förvisso inte alltid enig, men det fanns politiska ideal som gick att förstå även om man inte höll med om

En till engelska översatt version av den här artikeln har tidigare publicerats som "Punk, class and career", i Sven Hort (red.), From Linnaeus to the future(s) - letters from afar, Linnaeus University Press 2010. 
dem - mods och raggare hade kanske inga direkta mål, men de gick att kategorisera och var relativt begripliga i fråga om kläder och musik. Punken var oljud, trasiga kläder, säkerhetsnålar i kinderna och en attityd som mer handlade om att "skita i allt" än att uttrycka några åsikter som gick att bemöta eller bejaka. Punkens nihilistiska ideal bidrog till att skapa associationer till droger, våld och fascism. Kort sagt: punken upprörde, skrämde och fascinerade. Åsikterna om punken gick isär, men få som kom i kontakt med den lämnades oberörda. Ur detta har en mängd "sanningar" skapats: punkarna kan inte spela, punkarna är knarkare, punken är bara ett mode, punkarna är vilsna ungdomar med dystra framtidsutsikter, punkarna är våldsamma, med mera. Expressen beskrev en fjortonårig punkare:

Taktiskt politiskt är han dödsklantig. Han håller på invandrare, på arbetare, på kvinnor. Men invandrarna kommer inte runt läderjackan, arbetarna tycker han luktar knegarförakt, kvinnorna hakar upp sig på kedjorna och nålarna. Peter blir betraktad som rasist, fascist, manschauvinist, när det är precis tvärtom. Det är samma sak i plugget. Där finns andra som också är emot betygen, men de lierar sig inte med honom. Han kallar dem borgare.

Vissa av dessa "sanningar" var mer sanna än andra, andra blev sanna med tiden - kanske som ett resultat av den stämpling punkarna utsattes för - och mycket är naturligtvis en tolkningsfråga. Få i punkens samtid ägnade särskilt mycket energi åt att få substans i tolkningarna. När en ungdomsgrupp blir föremål för denna typ av associationer är det vanligen två förhållningssätt som följer beroende på hur gruppen betraktas: man tänker antingen att det kommer att gå åt helvete för allihop eller att det är en ungdomsrevolt som går över efter ett tag. Ungdomskulturen betraktas antingen som något som vi helst skall skydda ungdomarna mot eller som något som i princip alla går igenom utan att det lämnar några särskilda spår.

Det är tragiskt att se alla de här trenderna sammanstråla i en liten tjej på tunnelbanan mellan Ropsten och T-Centralen. Jag önskar att alla som sticker nålar genom kinden kunde fatta att de inte alls protesterar. Utan att de är offer och

I. Från http://www.punktjafs.com/ny/peter_punkı4.htm, hämtat Io januari 2008. 
reklampelare för kommersiella intressen långt, långt över deras huvuden. Det är ingen protest. Men det är ett allvarligt symptom på hur det här samhället lämnar de unga i sticket och lämnar dem åt den kommersiella världen att invadera deras kroppar och tankar. ${ }^{2}$

Många av de gamla punkarna har idag också bilden av punken som något som var kul i några år men som tillhörde en period i ungdomen och inte har haft någon särskild betydelse senare i livet.

\section{Minnet av punken}

Det finns anledning att säga några saker om hur minnet av punken skildras. Bilden av punken har förändrats påtagligt på de trettio år som gått. Ett tydligt exempel på detta är framställningen av punkarnas utseende. När vi diskuterar punk idag går associationerna gärna till en person med kängor, tuppkam och skinnjacka med nitar. I verkligheten var det knappast någon som hade tuppkam 1978, tuppkammen kom senare och har i princip ingenting med den första generationens punkare att göra. Punken har levt vidare och utvecklats, och det kan vara svårt att veta vilken tid våra minnen egentligen handlar om. ${ }^{3}$ För att det skall bli tydligare vad vi diskuterar vill vi slå fast några punkter, där vi misstänker att mångas minnen påverkats för mycket av punkens senare historia.

De flesta av punkarna såg inte ut på ett sätt som vi idag förknippar med punk. Ser vi bilder på den första generationens punkare ser de ganska städade ut. Några få tog ut svängarna med smink och säkerhetsnålar, men den genomsnittlige punkaren hade idag (med reservation för övergripande modeförändringar) överhuvudtaget inte avvikit från ungdomar i allmänhet. Den vanligaste klädseln var ett par slitna jeans och en T-tröja. Det många markerar som ett avgörande steg var att de klippte av sig håret. Punkarna ville markera avstånd från 1970-talets långa hår, som de förknippade med progg och hippierörelsen.

2. Maria-Pia Boëthius i Söndags-Expressen 22 maj 1977, citerat från http://www.punktjafs. com/ny/punk_mp_man_leder.htm, hämtat ıo januari 2008.

3. Det går att ha olika åsikter om i vilken mån punken är död eller levande, vad som är "riktig" punk etc. Helt klart är att det finns människor födda långt efter 1982 som kallar sig punkare och som själva ser en rak linje från 1977 till den kultur de företräder. 
Sedan började min uniformering, vilket jag naturligtvis gjorde en stor affär av i skolan. På en konst- och bildlektion la jag mig en dag på rygg på ett bord och sa att "nu ska jag göra konst" och klippte av mig håret. Till lärarens stora ilska. Jag ansågs vara lite underlig redan innan så det var nog inte så konstigt, men det var en stor grej. ("Aldo Morot" i Carlsson, Johansson \& Wickholm 2004: 13)

Samtidigt måste det sägas att punkarna då var mer provokativa och avvikande än vi kanske tänker oss idag. I medierna och för vuxengenerationen uppfattades punken som hotfull på riktigt. SVT presenterade nyheter om "punkmordet". ${ }^{4}$ Punkarna fick vänja sig vid att fly från raggare och andra grupper för att inte bli misshandlade. Aftonbladet citerade en raggare i maj 1977: "Tre spänn för varje utsliten säkerhetsnål och fem spänn om något av kinden följer med" (Carlsson, Johansson \& Wickholm 2004: I6). I takt med att punken blev mer musik- och klädstil och mindre motkulturell rörelse har minnet av detta sjunkit undan. Samma sak kan sägas om musiken: mycket av det som då kallades punk låter närmast mjukt och trevligt idag. ${ }^{5}$ Det är i många fall svårt att förstå vad som var så upprörande, eller ens ovanligt, men på samma sätt som med den yttre stilen ansågs musiken värre än vad vi kanske minns. Skälet till det är troligen att det efter den tidiga punken har kommit mängder av musik som är så mycket våldsammare, skränigare och konstigare att det idag knappt går att förstå hur punkbandens relativt traditionella rockmusik kunde vara så upprörande. En annan förklaring är den sociala dynamik som finns mellan en etablerad grupp och de som avviker från de etablerades normer. Vi definierar inte avvikare utifrån de genomsnittliga representanterna, utan utifrån de värsta (Elias \& Scotson 20IO). De punkare som avvek mest kom att definiera hela gruppen, och helt klart är att det fanns punkare som levde upp till den bild som skapades av dem. Det gällde inte alla och inte ens någon majoritet, men det är den bilden som slog igenom i delar av massmedierna och vuxengenerationen.

4. I februari 198I knivmördades en person utanför en tunnelbanestation i Stockholm. Gärningsmannen ingick i punkkretsarna och händelsen döptes till "punkmordet" och blev bland annat central för en film av Staffan Hildebrand, som typiskt nog handlade om sociala problem, sysslolöshet och droger.

5. Band och artister som Elvis Costello, Dag Vag, Tant Strul och Talking Heads skulle idag inte kallas punk med utgångspunkt i hur de låter. Då var de en självklar del av punken. 


\section{Våra utgångspunkter}

Olika generationer har olika bilder av vad punken är för något. Vi kommer i vår framställning att stanna vid den första generationens punkare, de som var aktiva mellan 1978 och 1982 . Det krävs omfattande studier för att undersöka de förändringar som punken har genomgått och det finns anledning att anta att såväl punkens betydelse som dess sociala sammansättning har förändrats. Första generationens punk uppvisar i sig så många sociala och kulturella egenheter att det finns anledning att undersöka hur den påverkade de inblandade. Vilka var punkarna? Vad gör de nu? Hade punken någon betydelse för dem? I samband med ett bokprojekt har den svenska punken mellan 1977 och 1982 kartlagts. ${ }^{6}$ Alla svenska punkband som gav ut någonting på skiva under den aktuella perioden har kontaktats och vi har fătt e-postadresser till dem. Vi skickade en enkät till 284 av punkarna och har fått 175 svar. ${ }^{7}$ Dessa svar ger oss fakta om vilka punkarna var och vad de gör idag och vi kan utan vidare säga att båda de ovan presenterade bilderna är felaktiga eller åtminstone ofullständiga. Det går inte att säga att det slutade illa för punkarna och de verkar inte heller vara opåverkade av punken.

\section{Punkarnas sociala bakgrund}

Inom populärkulturen är det vanligt att utgå från att nya eller avantgardistiska uttrycksformer kommer från "gatan", det vill säga från de folkliga klasserna, och att nya konstnärliga former är ett uttryck för utanförskap. De aktiva själva gör i allmänhet ingenting för att förändra den uppfattningen. Myten om den fattige, lidande konstnären som talar

6. Vi kan inte nog tacka Peter Kagerland och Mats Jönsson för det enorma detektivarbete de har lagt ner för att leta upp alla gamla punkare i vad som kom att bli boken Ny våg. Svensk punk, new wave, synth 1977-1982 (Kagerland 2012). Utan deras insats och nätverk hade vår studie inte gått att genomföra.

7. Definitionen av "punk" är helt avgörande för urvalet och kan kritiseras. Den är inte gjord på något vetenskapligt sätt utan bygger på en bedömning av hur musiken lät och uppfattades i sin samtid. Vår bestämda uppfattning är att någon annan kanske hade lagt till eller plockat bort några band, men knappast på något sätt som haft avgörande betydelse för populationens sammansättning. Punken var så pass avgränsad både socialt och kulturellt att några större avvikelser inte är möjliga utan att lämna begreppets vardagsspråkliga innebörder. 
ur ett underdogperspektiv är stark (se bl.a. Becker 1982; Zolberg 1990; Bourdieu 2000). Liknande idéer finns inom radikala politiska rörelser, där man kanske inte tror att medlemmarna kommer ifrån arbetarklassen men där det definitivt är en merit att göra det. Arbetarklassen, eller andra socialt underordnade grupper uppfattas som ett slags ideal för såväl "autentiska" uttryck som för politiska idéer. ${ }^{8} \mathrm{Vi}$ vet att detta vanligen är fel. De uttryck som intar ett underifrånperspektiv och som kommer att anses nya eller avantgardistiska kommer vanligen från medelklassen, medan arbetarklassen traditionellt föredrar det som lite slarvigt kan kallas "konventionella kulturuttryck". Punken är inget undantag. Vi kan konstatera att punken inte var någon arbetarklassrörelse. Detta är kanske inte särskilt förvånande, men trots allt intressant. Av punkarnas föräldrar ingår 20 procent i arbetarklassen och 29 procent är högre tjänstemän. Punkarna är socialt sett en kombination av en folklig klass (arbetare och lägre tjänstemän) och en etablerad medelklass.

\begin{tabular}{lc} 
Tabell I. Punkarnas sociala bakgrund (procent) \\
\hline Arbetare & 20 \\
Lägre tjänstemän & 20 \\
Tjänstemän på mellannivå & 23 \\
Högre tjänstemän & 29 \\
Företagare/lantbrukare & 9 \\
\hline $\mathrm{n}=\mathrm{I} 73$ & I00
\end{tabular}

Vi har alltså en ungdomskultur där majoriteten kom från de etablerade klasserna och där det ingick i uttrycket att ta avstånd från allt etablerat. Om punken hade en negativ påverkan, eller ingen påverkan alls, på dessa människor borde det vara ganska enkelt att se om vi studerar vad de gör idag: vi borde då hitta en fallande eller möjligen stabil social statusutveckling hos punkarna. Vi har också en stor minoritet från arbetarklassen som enligt vad vi vet om klassreproduktion borde ha lägre sociala positioner än genomsnittet. Här kommer emellertid vår vardagsförståelse på skam.

8. "Vi som hade proletär bakgrund var attraktiva för vänstern då. Det var inte som i slutet av 6o-talet då vi mer betraktades som lite dumma. Nu hade det blivit modernt att vara lite dum, trög och obildad" (Lundberg 1993: II6). 


\section{Punkarnas klassposition och utbildningsnivå}

Statistiken visar att punkarna, oavsett bakgrund, har högre sociala positioner än genomsnittet för motsvarande åldersgrupp i hela landet. Det mest anmärkningsvärda resultatet är att mer än 40 procent av punkarna (totalt) idag är högre tjänstemän, jämfört med knappt 20 procent av rikets män i samma åldersgrupp som helhet.

\begin{tabular}{|c|c|c|c|c|c|c|c|}
\hline \multirow[b]{2}{*}{ Position idag } & \multicolumn{6}{|c|}{$\begin{array}{r}\text { Punkare } \\
\text { Social bakgrund }\end{array}$} & \multirow{2}{*}{ 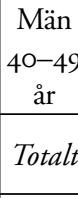 } \\
\hline & Arbetare & $\begin{array}{c}\text { Lägre } \\
\text { tjm }\end{array}$ & $\begin{array}{c}\text { Tjm på } \\
\text { mellannivå }\end{array}$ & $\begin{array}{c}\text { Högre } \\
\text { tjm }\end{array}$ & $\begin{array}{l}\text { Före- } \\
\text { tagare }\end{array}$ & Totalt & \\
\hline Arbetare & 28 & 15 & I I & 7 & 23 & IS & 39 \\
\hline Lägre tjänstemän & o & 3 & 8 & I7 & 8 & 8 & Io \\
\hline Tjänstemän på mellannivå & $3 \mathrm{I}$ & 30 & 46 & I5 & 8 & 28 & 19 \\
\hline Högre tjänstemän & 34 & 46 & 24 & 52 & 46 & 40 & 18 \\
\hline Företagare/lantbrukare & 6 & 6 & II & 8 & I5 & 8 & IS \\
\hline
\end{tabular}

Vi har vidare en population med osedvanligt hög utbildningsnivå. Personer med högstatusbakgrund tenderar att utbilda sig i högre grad än genomsnittet. Det finns emellertid en komplikation som gör siffrorna både intressantare och mer svårtolkade. Oavsett social bakgrund är utbildningsnivån inom populationen hög. I de grupper av punkare vars föräldrar är arbetare, lägre tjänstemän, tjänstemän på mellannivå eller företagare är minst 44 procent högskoleutbildade. Hela 70 procent av punkarna med föräldrar som är högre tjänstemän är högskoleutbildade, men det är mindre förvånande än att 52 procent av dem med föräldrar från arbetarklassen är högskoleutbildade. Om vi betänker att samma åldersgrupp i riket sammantaget ligger på 30 procent är siffrorna uppseendeväckande. Punkarna är en osedvanligt välutbildad grupp oavsett social bakgrund och detta faktum efterfrågar någon typ av förklaring. ${ }^{9}$

9. I den fortsatta framställningen utgår vi från följande sociala kategorier: folklig bakgrund (arbetare och lägre tjänstemän), etablerad medelklass (tjänstemän på mellannivå och högre tjänstemän) samt företagare/lantbrukare. 
Tabell 3. Högsta utbildning efter social bakgrund (procent)

\begin{tabular}{|c|c|c|c|c|c|c|c|}
\hline \multirow[b]{2}{*}{ Utbildning } & & & $\begin{array}{r}\text { Punka } \\
\text { ocial bakgrun }\end{array}$ & & & & \multirow{2}{*}{ 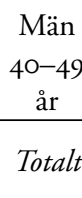 } \\
\hline & Arbetare & $\begin{array}{c}\text { Lägre } \\
\text { tjm }\end{array}$ & $\begin{array}{c}\text { Tjm på } \\
\text { mellannivå }\end{array}$ & $\begin{array}{c}\text { Högre } \\
\text { tjm }\end{array}$ & $\begin{array}{l}\text { Före- } \\
\text { tagare }\end{array}$ & Totalt & \\
\hline Grundskola & I3 & 6 & 6 & 4 & 7 & 6 & 18 \\
\hline Gymnasium 2 år & 23 & 25 & I6 & 15 & 20 & I9 & 40 \\
\hline Gymnasium 3 år & I 3 & 25 & 27 & I I & 7 & $I 7$ & $I 2$ \\
\hline Högskola < 3 år & IO & I6 & I9 & 26 & 33 & 20 & IS \\
\hline Högskola $\geq 3$ år & 42 & 28 & 32 & 45 & 33 & 37 & IS \\
\hline
\end{tabular}

\section{Problemdiskussion}

Vi kan konstatera att den kategori punkare som var mest engagerade och involverade, de som spelade och gjorde skivor, knappast har farit illa av sitt engagemang, åtminstone inte i strukturellt hänseende. Det trodde vi inte heller, men för den som möjligen oroade sig är detta faktum värt att slå fast. ${ }^{10} \mathrm{Vi}$ kan också problematisera påståendet att punken var en fas som skulle lämna de inblandade opåverkade. Vi vet att personer med bakgrund i de etablerade klasserna normalt genomgår högre utbildning oftare än personer från de folkliga klasserna (Forneng 2006). Så är det också i vårt material, men även punkarna från arbetarklassen har utbildat sig mer än riksgenomsnittet. Den höga utbildningsnivån kräver en förklaring, samtidigt som den är en delförklaring till de oväntat höga sociala positionerna. Att det bara är en delförklaring beror på att även de punkare som inte utbildat sig har högre sociala positioner än genomsnittet. Det är alltså inte bara utbildningsfrågan som är intressant. Yrkesval och karriärer, oberoende av utbildning, uppvisar också avvikelser i relation till riksgenomsnittet: även de punkare som inte utbildat sig har "bättre"

IO. Ett ostrukturerat material som vi samlade in som en preliminär förstudie visar att det finns en överrepresentation av individer som faktiskt farit illa. Ett antal av de gamla punkarna är döda, har missbruksproblem eller sitter i fängelse. Gruppen är liten men betydligt större än förväntat i relation till riksgenomsnittet. Detta vore ett intressant spår för vidare studier, men våra uppgifter är så osäkra att vi inte kan säga mer än att det vore intressant att undersöka vidare. 
jobb än genomsnittet. För den del som kommer från de etablerade klasserna kan detta förklaras av det sociala kapital klasstillhörigheten ger, men för punkarna från de folkliga klasserna måste vi hitta förklaringen någon annanstans. Båda grupperna är intressanta och om vi skall studera punken som ett socialt sammanhang måste vi ta hänsyn till både deras gemensamma sociala miljö och relationen dem emellan. Vi menar dock att det är punkarna från arbetarklassen som är intressantast. Det är för denna grupp som avvikelsen från det förväntade är störst. Fortsättningsvis kommer vi i den här artikeln att nöja oss med att försöka förklara denna grupps oväntade karriärer.

\section{Tänkbara förklaringar}

För att förklara punkarnas till synes märkliga karriärer finns det flera vägar att gå. Vi har tre tänkbara förklaringar:

- Punkarna var i något avseende ovanliga redan från början och punken var en katalysator för dessa egenskaper. Detta kan vi inte veta något om eftersom det inte fångas av de klassvariabler vi använt. För att kunna ge oss in på denna förklaringsväg behöver vi ett omfattande kvalitativt material.

- Punkens sociala sammansättning skapade en miljö som påverkade människors val och möjligheter.

- Deltagandet i punken gav något slags resurser som kunde komma till nytta i en framtida utbildnings- och yrkeskarriär.

Den första punkten lämnar vi därhän tills vidare. Den andra punkten har vi idéer om. De är än så länge spekulationer, men de är så pass riktade att vi skall utveckla dem längre fram i texten. Den tredje punkten kan vi säga en del om utifrån de data vi har: vi har ställt frågor om punkarnas koppling till kultursektorn och om deras nuvarande yrken och det visar sig att en stor andel har yrken som går att knyta till de aktiviteter som kännetecknade punktiden. 


\section{Punkens "gör det själv"-ideal}

Det finns många sätt att beskriva punken, men om vi bortser ifrån attributen och hur det faktiskt lät eller såg ut är det få som skulle invända mot att punken var en kulturform där ett av de viktigaste inslagen var att man skulle göra saker och man skulle göra dem själv, utan professionell hjälp.

Jag hade ett behov av att få ur mig saker och att göra en tidning var en naturlig del av punken. Även om ditt uttryck är destruktivt - så var grundkravet att du skulle uttrycka dig. Det spelade ingen roll vad du gjorde eller hur du gjorde det. Bara du gjorde något. Ställ dig och slå sönder något eller bygg upp något. ("Aldo Morot" i Carlsson, Johansson \& Wickholm 2004: 36)

Jag hade alltid velat skriva, men aldrig fattat hur man gjorde. Jag hade dåligt självförtroende och var för blyg för att fråga någon. Ett fanzine var enkelt kopierat och häftat i hörnen. Jag såg direkt att detta var något jag kunde göra själv. (Magnus Hagström i Carlsson, Johansson \& Wickholm 2004: 38)

Det är alltför lätt att se punken som en kombination av musik, mode och attityd, men engagemanget och aktiviteten innehöll mycket mer. Punkarna startade tidningar, musikföreningar, festivaler, radioprogram och skivbolag. De arrangerade konserter och designade affischer och skivomslag. De lärde sig teknik för att arbeta i studio och sköta ljud och ljus för banden live. De startade bokningsbolag och fotoklubbar. De skrev musik, texter, poesi, romaner och artiklar. De målade, fotograferade och var politiskt aktiva på olika sätt.

Punken var ett sammanhang där man gjorde saker och lärde sig hur de skulle göras. Även om det är en myt att inga punkare kunde spela är det sant att den professionella skickligheten var lågt värderad och att vem som helst fick göra saker utan att egentligen kunna. Det innebär inte att allting gjordes dåligt och amatörmässigt - det innebär att det fick göras dåligt och amatörmässigt. Efter hand ökade kraven och banden lärde sig spela, studioteknikerna lärde sig mixa och fotograferna lärde sig framkalla bilder. Skivbolagen blev tvungna att interagera med butiker, distributörer, skivpressare och etablerade medier. Det gjorde att trycket på en ordnad ekonomi och en fungerande organisation ökade. Punkens 
publik breddades och arrangörerna tvingades (eller fick möjlighet?) att möta en bredare publik med högre krav på ordnade och väl marknadsförda arrangemang. De tidningar som startades som maskinskrivna stencilutgåvor utvecklades till mer professionella alster.

Punken födde en kultur som sänkte alla krav. Det gick att starta från grunden och det var enkelt att göra ett fanzine. Jag plöjde Popen idag 76-77 varje kväll och där stod det om en kille som gick upp till Island records och kom därifrån med två skivetiketter. Det lät som en dröm. Min idé var att börja med ett fanzine och utveckla det till ett skivbolag. Så jag började klippa och klistra. [...] Jag bokade Musikverket för en new-wave-gala två dagar i augusti 1979. Jag ville få ihop ett skivbolag genom att ge ut en skiva, "Live på verket". Jag affischerade ner hela stan. Danne från Bitch Boys skötte inspelningen. Vi körde allt genom ett mixerbord, genom en kanal. Vi visste inte bättre. Det blev fullt hus i två dagar och 17 ooo kvar i kassan. Ljudet blev uruselt men det fick duga till en EP. [...] Jag och Anders Tapper drev [skivbolaget] Stranded hemifrån mina föräldrar. Efter ett år var pengarna slut och vi bytte distribution från MNW till Stikkan Andersons Polar. Det var kontroversiellt, och det gick rykten om att Aldo Morot skulle döda mig för att jag hade sålt mig till kapitalet. Sedan kom första singeln med Ratata och "Stilla nätter i Clichy" med Lustans Lakejer. Det blev genombrottet. (Klas Lunding i Carlsson, Johansson \& Wickholm 2004: 5I)

Den som ville fortsätta på den amatöristiska nivån kunde göra det, men många av punkarna befann sig i en miljö där det fanns gott om möjligheter att lära sig saker. Detta är tydligt i efterhand; då höll man troligen bara på. Det fanns motstånd mot professionaliseringen och många insåg sina begränsningar, men för dem fanns det andra saker att göra. Den som inte kunde spela kunde mixa ljus och den som inte kunde fotografera kunde skriva.

Den 9 september 1978 hade vi vår första RIP-gala ${ }^{\text {II }}$ på Jarlateatern. Vi hyrde stället för 400 kronor. Då ingick det en vaktmästare. Jarlateatern tog in 400 pers. Allt var kaos. Vi visste ju ingenting om sådant här och hade lånat tre små sånganläggningar som vi hade tänkt sätta ihop på något sätt. Medan vi stod och undrade över hur de fungerade växte kön utanför. Allt sket sig. Banden drog. Folk hade sönder inredningen. Men vi fick ingen reprimand eller så. Vi var I5-I6 år och bokade en teater och det var liksom inga problem. Det kom aldrig någon räkning i alla fall. (Micke RIP i Carlsson, Johansson \& Wickholm 2004: 40)

II. RIP var en tidning som utvecklades från ett stencilfanzine till en professionellt utformad tidskrift. 
Vi menar att denna kreativa amatörism kan ha varit punkens viktigaste bidrag till de människor som var aktiva. Även om man drogs till punken av ett intresse för musiken eller attityden fick man automatiskt möjlighet att utveckla en mängd olika färdigheter på sitt eget sätt och i sin egen takt. Någon som började spela bas i ett band efter att ha hört Ebba Grön på radion kanske kom att ägna sin mesta energi åt en egenproducerad tidning och tog steget till en journalistutbildning utan att någonsin tidigare haft en tanke på det. En annan basist kanske tog aktiv del i att göra bandets skivomslag och utvecklade talanger som senare gjorde det möjligt att arbeta med videoproduktion.

Vi blev uppringda av SAM-distribution, men vi tackade nej direkt. Vi ville göra allt själva. När punken kom var vi lite av gamlingarna, över 20 år, men det var alltid självklart att göra egna låtar och sjunga på svenska. Vårt syfte var att ha kul även om texterna var politiska och ofta kritiserade media. Idag jobbar flera av oss med reklam och media. (Håkan Sandsjö i Carlsson, Johansson \& Wickholm 2004: 193)

\section{Yrken}

Punkare med folklig klassbakgrund har högre positioner och högre utbildning än de kan förväntas ha i en riksjämförelse (se tabell 2 och 3). Det gäller även dem som saknar högre utbildning. För att återknyta till diskussionen ovan är det värt att titta närmare på vilka positioner de har.

Att vara yrkesverksam musiker är svårt och sällsynt, men punken handlade inte bara om att spela utan kan ha förberett många för liv som studioägare, journalister, kulturbyråkrater och arbete med film, reklam och design. Påfallande många har dessa och andra yrken som på ett eller annat sätt kan knytas till kultursektorn. Hela 44 procent av punkarna är idag på något sätt yrkesverksamma inom denna sektor. Det gäller 42 procent av punkarna med folklig bakgrund, 47 procent av punkarna från etablerad medelklass och 36 procent från företagar- eller lantbrukarhem. Vi har därför anledning att tro att punkens bieffekter, det som hände vid sidan av själva spelandet, har haft stor betydelse för de inblandades karriärmöjligheter. 
Inom vilka områden hamnar kulturpunkarna? Vi har delat upp kulturbranschens yrken i musikrelaterade, övrigt konstrelaterade, "reklam, medier, film" samt övriga kulturrelaterade yrken (exempelvis musikpedagog, konstkritiker och musikarkivarie). "Reklam, medier, film” är den sektor störst andel av kulturpunkarna, oavsett social bakgrund, verkar inom: 53 procent.

Kulturpunkare tillhör idag den etablerade medelklassen i högre grad än övriga punkare (se tabell 4) - oavsett social bakgrund. Av kulturpunkarna med folklig bakgrund är 43 procent högre tjänstemän. Det verkar alltså rentav vara så att det bland de punkare som har folklig bakgrund är just kultursektorn som har möjliggjort en klassresa. Detta mönster återfinns inte bland medelklasspunkarna, där en större andel av dem som orienterar sig mot andra yrkessektorer än kultursektorn intar högre tjänstemannapositioner.

"Klassresenärsfenomenet" är speciellt tydligt bland de folkliga punkare som arbetar inom reklam, medier och film. Hela 57 procent i denna grupp tillhör idag gruppen högre tjänstemän och ingen har ett folkligt yrke, det vill säga arbetare eller lägre tjänsteman. Punkare med folklig bakgrund har högre sociala positioner än motsvarande grupp i riket i övrigt. Det innebär att två av de förklaringsmodeller vi tidigare diskuterat verkar relevanta: det handlar om både punkens sociala sammansättning och skapandet av en unik miljö som att deltagande i punken gav resurser för framtida livschanser.

\section{Tabell 4. Nuvarande social position bland kulturpunkare och övriga punkare efter social bakgrund (procent)}

\begin{tabular}{|c|c|c|c|c|c|c|c|c|}
\hline \multirow[b]{3}{*}{ Position idag } & \multicolumn{6}{|c|}{ Social bakgrund } & \multirow{2}{*}{\multicolumn{2}{|c|}{ Totalt }} \\
\hline & \multicolumn{2}{|c|}{ Folklig } & \multicolumn{2}{|c|}{ Medelklass } & \multicolumn{2}{|c|}{ Företagare } & & \\
\hline & Kultur & Övr & Kultur & Övr & Kultur & Övr & Kultur & $\ddot{O} v r$ \\
\hline Arbetare & 7 & 32 & 3 & I3 & 0 & 38 & 4 & 23 \\
\hline Lägre tjänstemän & 4 & o & I4 & I 3 & 20 & o & IO & 7 \\
\hline Tjm på mellannivå & 43 & 22 & 46 & I5 & 20 & o & 43 & $I 7$ \\
\hline Högre tjänstemän & 43 & 38 & 32 & 46 & 60 & 38 & 39 & $4 I$ \\
\hline Företagare/lantbr & 4 & 8 & 5 & $\mathrm{I} 3$ & 0 & 25 & 4 & 13 \\
\hline
\end{tabular}




\section{Vilket slags sammanhang var punken?}

Den andra förklaringen vi tog upp ovan handlade om punken som en social miljö som påverkade människors val och möjligheter. Punken skilde sig från andra rörelser i det att den var så klassblandad utan att det ledde till grupperingar eller motsättningar (Lundberg 1993). Vi menar att detta kan ha haft betydelse för punkarnas karriär och utbildningsval. Flera studier visar att i de miljöer där arbetarklassens barn möter medelklassens ökar sannolikheten för att även arbetarbarnen söker sig till högre utbildning (Bourdieu \& Passeron 2008; Jönsson, Trondman, Palme \& Arnman 1993). Vanligen sker det när de olika grupperna tvingats samman i skolor eller bostadsområden. Punken var inget sådant sammanhang - snarast är det konstigt i sig med en ungdomskultur som är klassblandad utan att vara mainstream. Vi skall komma ihåg att punken var en liten, om än högljudd, kulturyttring. Det var inget sammanhang som lockade genom att vara allmänt accepterat, snarare uppfattades punken som frånstötande och mötte motstånd från andra ungdomsgrupper. Att punken trots detta kunde attrahera olika grupper utan avgörande inre motsättningar är anmärkningsvärt och leder till frågan vad för slags socialt sammanhang punken var.

Punken i Sverige är inte alldeles lätt att klassificera. Helt klart är att det rör sig om en ungdomskultur, men det är också något mer. Ungdomskulturer är ofta stil- och smakmässigt homogena men saknar utvecklad social gemenskap mer än på väldigt lokal nivå. De går också ofta att bestämma relativt väl i fråga om bärarnas sociala bakgrund. Punken var påtagligt klassblandad samtidigt som det fanns sociala nätverk, gemenskaper och samarbeten på nationell nivå. ${ }^{12}$ Jämfört med många andra ungdomskulturer var punkarna mer aktiva producenter av sitt eget uttryck. Punken var i lika hög grad ett socialt sammanhang och en aktivitet som en stil och en smak.

Trots att det ofta talas om "punkrörelsen" är vi tveksamma till att tala om punken som en social rörelse. Sociala rörelser kännetecknas av ett kollektivt handlande i syfte att uppnå ett mer eller mindre klart uttalat

I2. Att det gick att samla ihop och avgränsa punkare över hela landet till ett bokprojekt bekräftar detta. 
mål (Bjurström 1997; Eyerman \& Jamison 2005; Ring 2007). Vanligen associeras sociala rörelser med politiska ideologier. Punken hölls inte samman av något sådant. Det fanns förvisso punkare med klart uttalade politiska idéer, men stora delar av punken var närmast anti-politisk och andra brydde sig inte alls. Punken brukar diskuteras som en anarkistisk rörelse, men för många betydde detta snarare anarki än anarkism. Det verkar därför rimligare att diskutera punken som en motkultur än som en social rörelse (Bjurström 1997). Att punkarna var "mot" skulle de flesta hålla med om. De var motståndare till vuxengenerationen, det etablerade samhället, kommersialismen, masskulturen och en hel del annat. Några politiska visioner eller alternativa samhällsalternativ presenterades mycket sällan och av ett litet fåtal. Det alternativ som fanns var det som låg inbyggt $\mathrm{i}$ den egna aktiviteten. Någon samlad idé fanns knappast, men det fanns en samlad aktivitet. Häri ligger kanske också svaret på den fråga som måste ställas: Hur hölls punken samman? Vi antar att de flesta ungdomskulturer hålls samman på lokal nivå och genom identifikation med de former som presenteras. En social rörelse hålls samman av de mål den formulerar. Punken hölls samman på nationell nivå utan några sådana mål. Som motkultur hölls punken samma genom att punkarna själva utgjorde alternativet till det de protesterade mot. Väldigt få av punkarna var passiva. Att vara punkare var detsamma som att på ett eller annat sätt vara aktiv i produktionen av kulturens uttryck.

Vi tror att just detta utgjorde såväl lockelsen som det sammanhållande kittet. Punkens omedelbara attraktionskraft låg i möjligheten att göra saker i ett socialt sammanhang, utan styrning och utan krav på kunskap eller professionalitet. Det påminner om att "leka” musiker eller arrangör, med den avgörande skillnaden att det var skarpt läge. Det fanns en publik, det fanns ett mediaintresse och det som hände var på riktigt. Ideologin som höll alltihop samman kan kallas "gör det själv", och den fungerade lika bra för den som ville ha skoj med sina kompisar som för den som ville utveckla någonting på en framtida professionell nivå. Uttrycken var mer differentierade än mycket historieskrivning tillåter oss att minnas. Men eftersom startskottet och inspirationen för alla kom från punkens "gör det själv"-ideal fanns det en kort men gemensam historia 
där kontakten med Ebba Grön, Sex Pistols eller Ramones ${ }^{13}$ fungerade lika bra för den som ville "leka", för den som ville irritera föräldragenerationen och för den som ville satsa på musiken fullt ut. Vi kan anta att de flesta som mest ville ha lite kul kom från medelklassen och att läroprocesserna hade störst betydelse för arbetarklassen, men engagemanget verkar ha haft betydelse för många individer i alla grupperna.

\section{Avslutning}

Detta är en första presentation av resultat och innehåller både sådant vi kan uttala oss ganska säkert om och sådant vi avser att arbeta vidare med. Det vi kan påstå är att punkarna har högre utbildning och högre sociala positioner än förväntat, i synnerhet punkarna med folklig bakgrund. Vi diskuterar två förklaringar. För det första menar vi att punken erbjöd läroprocesser som gav resurser som kunde utnyttjas i yrken och utbildningar. Vi kan inte uttala oss säkert om läroprocesserna, även om det finns sekundärmaterial som ger stöd åt idén, men våra data tillåter oss att betrakta det som en rimlig hypotes. De folkliga punkare som har gjort karriär har i huvudsak gjort det inom kultursektorn, det vill säga de arbetar idag med saker som har med aktiviteten under punkåren att göra. Mellanledet, läroprocesserna, återstår att undersöka och kräver ett kvalitativt material. För det andra menar vi att utbildningsalternativet blev synligt för de folkliga punkarna genom att punken innebar kontakt med andra samhällsklasser. Vi vet att punken var klassblandad, men om detta hade betydelse, och i så fall hur, kan vi inte säga något om utan tillgång till ytterligare material.

Studien kommer att fortsätta enligt dessa hypoteser. Vi avser att göra ett antal intervjuer med punkarna för att få grepp om vad det sociala sammanhanget och aktiviteten innebar. Förhoppningsvis får vi då mer kunskap om hur yrkes- och utbildningsval påverkas av tillhörigheter och praktiker som till synes handlar om helt andra saker.

I3. Enkäten innehåller en fråga om vilka tre skivor som inspirerade under punkåren och det är påfallande hur överens punkarna är. 


\section{Referenser}

Becker, Howard S. (1982) Art worlds. Berkeley: University of California Press.

Bjurström, Erling (1997) Högt \& lågt. Smak och stil i ungdomskulturen. Umeå: Boréa.

Bourdieu, Pierre (2000) Konstens regler. Det litterära fältets uppkomst och struktur. Stehag: Brutus Östlings bokförlag Symposion.

Bourdieu, Pierre \& Passeron, Jean-Claude (2008) Reproduktionen. Bidrag till en teori om utbildningssystemet. Lund: Arkiv förlag.

Carlsson, Benke; Johansson, Peter \& Wickholm, Pär (2004) Svensk punk 1977-8I. Varför tror $d u$ vi låter som vi låter. Stockholm: Atlas.

Elias, Norbert \& Scotson, John L. (20I0) Etablerade och outsiders. 2 uppl. Lund: Arkiv förlag.

Eyerman, Ron \& Jamison, Andrew (2005) Sociala rörelser $i$ en ny tid. Lund: Studentlitteratur.

Forneng, Stig (red.) (2006) Universitet \& högskolor. Högskoleverkets årsrapport 2006. Stockholm: Högskoleverket.

Jönsson, Ingrid; Trondman, Mats; Palme, Mikael \& Arnman, Göran (1993) Skola - fritid - framtid. En studie av ungdomars kulturmönster och livschanser. Lund: Studentlitteratur.

Kagerland, Peter (2012) Ny våg. Svensk punk, new wave, synth 1977-1982. Stockholm: Premium Publishing.

Lundberg, Svante (1993) Sextioåttor. Studie av en politisk generation. Stockholm: Brutus Östlings bokförlag Symposion.

Ring, Magnus (2007) Social rörelse. Begreppsbildningen kring ett mångtydigt fenomen. Lund: Sociologiska institutionen.

Zolberg, Vera L. (1990) Constructing a sociology of the arts. Cambridge: Cambridge University Press. 


\title{
PER DANNEFJORD
}

\section{Organisationspraktiker och målförändring}

\author{
Exemplet svensk socialdemokrati
}

Varför ändras organisationers mål? Är det för att ledningen av olika skäl överger, förråder eller sviker de ursprungliga målen? Är det för att alla organisationer lyder samma obönhörliga lagar och blir alltmer lika?

Per Dannefjord vill ge ett nytt svar på några av organisationsteorins gamla frågor. Som exempel använder han det socialdemokratiska partiets programutveckling mellan 1889 och 1944. Partiet gick ifrån en uttalad revolutionär målsättning till en reformistisk och samarbetsinriktad. Var denna målförändring en följd av medvetna beslut?

Ur exemplet utvecklar Dannefjord en generell modell för hur och varför organisationers mål förändras.

Arkiv förlag 2009, 328 sidor

\section{Arkiv}

